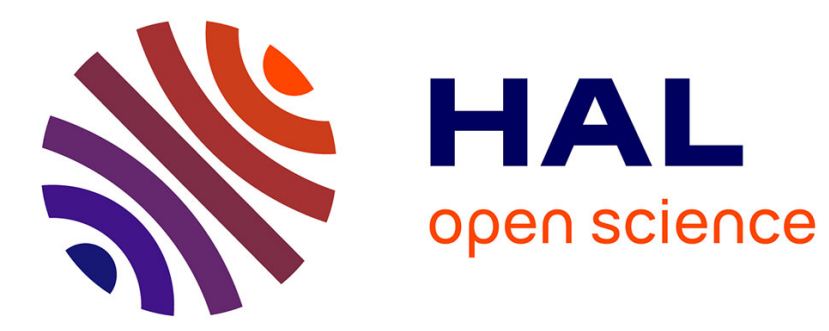

\title{
Categorising farming practices to design sustainable land-use management in mountain areas
}

Nathalie N. Girard, Michel M. Duru, Laurent Hazard, Daniele D. Magda

\section{To cite this version:}

Nathalie N. Girard, Michel M. Duru, Laurent Hazard, Daniele D. Magda. Categorising farming practices to design sustainable land-use management in mountain areas. Agronomy for Sustainable Development, 2008, 28 (2), pp.333-343. 10.1051/agro:2007046 . hal-02656904

\section{HAL Id: hal-02656904 https://hal.inrae.fr/hal-02656904}

Submitted on 30 May 2020

HAL is a multi-disciplinary open access archive for the deposit and dissemination of scientific research documents, whether they are published or not. The documents may come from teaching and research institutions in France or abroad, or from public or private research centers.
L'archive ouverte pluridisciplinaire HAL, est destinée au dépôt et à la diffusion de documents scientifiques de niveau recherche, publiés ou non, émanant des établissements d'enseignement et de recherche français ou étrangers, des laboratoires publics ou privés.

$$
\text { Copyright }
$$




\title{
Categorising farming practices to design sustainable land-use management in mountain areas
}

\author{
N. GIRARD*, M. DURU, L. HAZARD, D. MAGDA \\ INRA, UMR AGIR 1248, BP 52627, 31326 Castanet Tolosan Cedex, France
}

(Accepted 5 September 2007)

\begin{abstract}
In European mountain areas, shrub encroachment resulting from farmland abandonment is most often managed by mechanical operations such as roller chopping or controlled burning, which have proved to be ineffective and unsustainable. Recent agroecological findings highlight the potential impact of grazing on long-term shrub dynamics. We thus explored the potential contribution of livestock farms to the management of shrub encroachment. We studied the diversity of livestock practices and strategies on the scale of a small mountain valley in France where a land-use management plan was initiated. We interviewed 33 livestock farmers with a comprehensive approach and analysed the data in partnership with local land-use managers. To categorise farming practices, we used an innovative constructivist method based on knowledge engineering techniques and tools such as repertory grids. Our results show that the diversity of land-use practices can be summed up by ten practices related to three management domains: (i) livestock management, that is, splitting herds into batches, leading animals to pasture and breeding choices; (ii) the feeding system, including indoor feeding during the year, the hierarchy between haymaking and grazing in spring and the system's forage autonomy; and (iii) farmland utilisation and maintenance, which comprises hillside use, spatial configuration of grazed areas, maintenance practices and technical choices to cut meadows. We also show that farmers combine these practices within six types of strategies: ensuring feeding security and simplifying labour (type A), maintaining farmland heritage (type B), taking advantage of hillsides (type C), focusing on animal care (type D), combining areas, periods and batches (type E), or selling on local markets (type F). This makes it possible to identify: (1) farmers' strategies that have the greatest impact on shrub encroachment; and (2) practices that may develop into more sustainable management of shrub encroachment. Our work is thus a first step in developing sustainable land-use management plans in rural areas threatened by shrub encroachment. In return, this deep understanding of farmers' strategies allowed us to address socially pertinent scientific issues related to the dynamics of grazed plant communities.
\end{abstract}

agro-ecosystem management / livestock farming practices / grazing / modelling / shrub encroachment / typology

\section{INTRODUCTION}

During the 20th century, rural depopulation and agricultural modernisation have led to important changes in human land use, especially in mountain areas. In European mountain areas, the general agricultural decline is largely responsible for abandonment of farmland and its subsequent encroachment by shrubs and trees (Plieninger, 2006). Encroachment of mountain landscapes in Europe is part of a global trend that results from ubiquitous socio-economic driving forces (Mottet et al., 2006). It raises environmental stakes for both the conservation and development of natural heritage and the prevention of natural risks such as avalanches and fires (Swift et al., 2004). Moreover, farms concentrate their activities on the most favoured areas. With the growing concern of agricultural multifunctionality, pastoral farming systems fulfil both a production and an environmental function (Andersen et al., 2004). Maintaining pastoral activities in rural areas is crucial to maintaining employment as well as open landscapes and biodiversity (Buller et al., 2000). Since 1992, the implementation of agri-environmental and environmental policies has encouraged land managers and conservationists to no longer

\footnotetext{
*Corresponding author: girard@ toulouse.inra.fr
}

consider farming practices as perturbations, but as means to monitor ecological systems (Mattison and Norris, 2005).

Sustainable land-use management in mountain areas should be based on husbandry practices and grazing management that limits shrub encroachment. Controlled burning or mechanical operations such as roller chopping are necessary to restore open areas in the midst of shrubby vegetation. However, they are not sufficient to control shrub encroachment. In most cases, they enhance sprouting and seed germination that reinforces shrub dominance (Bravo, 1980). Nevertheless, grazing appears to be the best way to slow down shrub population dynamics on a long-term basis (Wallis de Vries et al., 1998). The sustainability of shrub encroachment control should thus involve appropriate grazing management of domestic flocks.

Since livestock density is low in these areas, new management strategies are therefore needed to have an impact on the shrub population with lower stocking rates and less frequent and shorter grazing sequences. To control shrub encroachment, farmers should adjust or change their grazing practices by, for example, combining grazing with mechanical means or changing the length of grazing periods, etc. They should also reconsider using types of vegetation and hillsides that they no longer use. Such changes may be facilitated if a 
land-use management plan provides the opportunity to make pastoral improvements such as fences, watering points and access roads. For all of these reasons, limiting shrub encroachment is a broader issue than just defining the best control technique. The Transfer of Technology model is therefore inadequate when dealing with natural resource management. On the contrary, researchers should adjust their activities to include a deeper understanding of local farming systems (Douthwaite et al., 2003). Moreover, land managers need to be familiar with farming practices so as to take them into account when designing land-use management plans.

However, classical approaches for characterising grazing practices are inadequate. Grazing practices are usually characterised by calculating average stocking rates and grazing pressures at farm or regional levels. These indicators may be considered as surrogate measures of biophysical sustainability (Pearson et al., 2003). However, because of the strong heterogeneity between and within farms and land units (Van Keulen, 2006), such quantitative criteria do not constitute a relevant pathway to examine and to understand the real utilisation of these areas (White et al., 2004). Moreover, they do not account for the local inhabitants' perception of their land resources, which is one of the key factors for explaining the diversity of farming practices (Beyene et al., 2006). Quantitative criteria characterising grazing practices ignore the reasons why farmers choose them and can therefore not account for the human dimension of sustainability (Röling, 2003).

As has been reported by other authors, this article acknowledges that the diversity of farming practices may prove to be an asset for the development of sustainable agriculture (Tefera et al., 2004; Beyene et al., 2006; van Keulen, 2006). On the one hand, there are many ways of using land within a farm, due to land characteristics as well as livestock management options at the seasonal level (Andrieu et al., 2007). On the other hand, we assume that the complementary nature of farms may prove to be an asset for identifying their potential role in shrub encroachment management.

Nevertheless, there is a wide range of approaches to the way researchers study and represent the heterogeneity or variability of local systems, as shown by van Keulen (2006) in his editorial. According to Röling (2003), two different viewpoints exist at the same time: (i) one that analyses agricultural sustainability through "causes and effects", linking agronomical and/or ecological results to technical and/or economic indicators (the impact of production systems on biophysical systems); and (ii) one that looks to human reasons for agricultural sustainability, in terms of values and goals, theory, perception of context and action. From the latter point of view, the bases for farming practices and systems may then be found, for example, in farmers' conceptions about the role of $\mathrm{N}$ in apple orchards when dealing with fertilisation practices (Nesme et al., 2006), in farmers' perceptions of their land resources, and in the local history of tenure and patterns of inheritance (Beyene et al., 2006) or in livelihood strategies (Tefera et al., 2004).

Characterising the diversity of farming practices and analysing the reasons why farmers do what they do may facilitate discussions between farmers and land-use managers faced with shrub encroachment problems. This assumption is in ac- cordance with what Röling (2003) calls "the human dimension of agricultural sustainability". Our work can therefore be seen in the tradition of "problem-finding" (Simon, 1978) research, in which it is essential to create a "Rich Picture" of the situation (Checkland, 1981) or a platform for social learning for natural resources management (Röling and Jiggins, 1998). These representations aim to be "models relevant to debate about changes" (Ison, 1993) or even "learning tools" (Walker, 2002). The land-use practices actually carried out by farmers make sense within their combined spatial and temporal framework, as shown by several authors (Girard et al., 2001; Biarnès et al., 2004). We characterise this combination of practices as "accomplished strategies", which are both deliberate, i.e., planned with specific goals in mind and emerging from circumstances and opportunities (Mintzberg and Waters, 1985). The "accomplished strategy" of a farmer thus represents the $a$ posteriori coherence of the practices he has carried out over the course of a year. Farmers' strategies are largely unrecognised since no statistical data and very little expert knowledge are available (Girard, 2006). Characterising such diversity of individual strategies is therefore a first step in understanding local farming systems that would help develop a realistic landuse management plan.

In partnership with the local designers of a future land-use plan in the Arreau Valley (central French Pyrenees), we aimed at identifying the potential roles of livestock farms in managing shrub encroachment. We thus assessed the diversity of individual strategies of farmers regarding land use in this valley. Our purpose was to identify farmers whose practices have an impact on encroachment, or farmers who may be encouraged to change some of their practices to fulfil land-use management objectives.

Our field work helped us to identify relevant scientific issues related to grazing practices and shrub encroachment control. It is an example of how a better understanding of the systems on which researchers work help them to adjust their activities and outputs accordingly, as observed by Douthwaite et al. (2003). Our study was thus built on an interdisciplinary basis (see Fry et al., 2004), bringing ecological, agronomical and knowledge engineering approaches together in order to study land-use practices from a systemic point of view, in accordance with Mattison and Norris (2005).

\section{MATERIALS AND METHODS}

\subsection{Study area}

We carried out our study in the Arreau Valley, which is located in the heart of the central French Pyrenees (see Fig. 1). In this mountainous region located in south-western France, land-use changes have followed the same trend as in other European mountain regions, with a general decrease in the number of farms and livestock units. Farmland abandonment is particularly true in the Central Pyrenees because of the landholding situation, the lack of pastoral equipment, the difficult accessibility of sloped areas and a lower average number of 




Figure 1. Location of the study area in southwestern France.

livestock units than the ones on either side of the Pyrenean massif.

The Arreau Valley stretches over a north-south axis, which links the piedmont with summits bordering Spain. The climate is typical of Atlantic mountain areas with a wide range of temperatures and moderate annual precipitation $(1200 \mathrm{~mm})$. Its hilly terrain consists of a plain taken up by lowland, located at between 650 and $800 \mathrm{~m}$ in altitude, and steep slopes. In the Pyrenees, current land-use organisation is generally inherited from the traditional organisation of past agro-pastoral systems. The farmland is mainly located in three areas (Balent and Gibon, 1999):

- The bottom of the valley, which mainly consists of private grasslands used for cutting and grazing;

- The mountain plateaux located at the top of the mountain and which are used by all of the farmers for summer grazing alone;

- Between the two former areas, the hillsides, which are characterised by their geographical location: they encompass all of the areas, private as well as communal ones, located between the bottom of the valley and the mountain plateaux. These hillsides are the most densely shrub-encroached areas of the valley.

The Arreau Valley has many characteristics very common to these mountain areas, such as an elderly population and a strong tourist potential. As elsewhere in the Pyrenees, its agriculture is fragile, with a decrease in the number of farms (179 in 1979, 121 in 2000), a concentration of remaining farms on cultivated areas and an increase in the average Utilized Agricultural Area.

\subsection{The Arreau Valley land-use management plan}

In 2002, a local multidisciplinary intercommunal agency, known as a SIVOM, initiated the design of a land-use management plan in order to "fight against farmland abandonment and manage land-use conflicts" in this very scenic and touristic valley. At that time, locally-elected officials were confronted with the problem of shrub encroachment, which was seen as being very unfavourable to tourism. One objective of the land-use management plan was thus to clear scrub and to maintain open landscapes.

In this context, we planned an action-research project within the framework of a large research-development programme, known as the "Programme On and For Regional Development" (PSDR), and financially supported by the MidiPyrenees region and INRA. Within our PSDR programme, we set up a working group together with the technical committee of the SIVOM of Arreau. This committee consists of territorial authorities, state representatives, locally-elected officials and agents from extension services. It has an advisory role for the elected officials of SIVOM and, when required, it may also draft proposals. In partnership with the SIVOM, we studied farming practices using the categorisation method presented below, with comprehensive interviews and collective analysis of the data obtained.

\subsection{The successive stages in a participative categorisation process}

The objectives of farm categorisation vary considerably (Girard, 2006). On one hand, segmentation methods such as those proposed by Köbrich et al. (2003) attempt to reveal the diversity inherent in data collected on a large sample of farms. On the other hand, constructivist methods attempt to represent farm diversity with a specific objective and viewpoint.

We used one of these constructivist methods (Girard et al., 2001; Girard, 2006) based on knowledge engineering tools, using case studies and the knowledge of researchers and local land-use managers as a basis. As a result, categories of farmers are not defined using automated methods but, on the contrary, stem from a certain number of hypotheses on the nature of the studied object. By producing such constructed categories, we adhere to most of the typology approaches currently being developed in France (Landais, 1998) and which all rely on the theory of farm operation considered as a complex managed system (Girard et al., 2001). Nevertheless, the method used is unique in that:

- It focuses on the categorisation of farming practices instead of evaluating technical and economic variables. It then expresses the qualitative nature of these practices without reducing them to quantitative parameters;

- It is linked to local specific practices and land-use management issues in order to build a specific typology rather than a generic one. The objective is to reformulate these issues through a deep understanding of husbandry practices.

The method is supported by a collective approach and knowledge engineering tools such as repertory grids (Bradshaw et al., 1993). The aim is to collectively define types of practices concerning the project participants and the problem(s) they want to tackle. Our approach thus combined interviews with farmers and a formalisation process during meetings with local stakeholders, in an iterative three-stage approach:

- Stage A consists of building a database identifying persons with an agricultural activity, the choice of a sample for the 


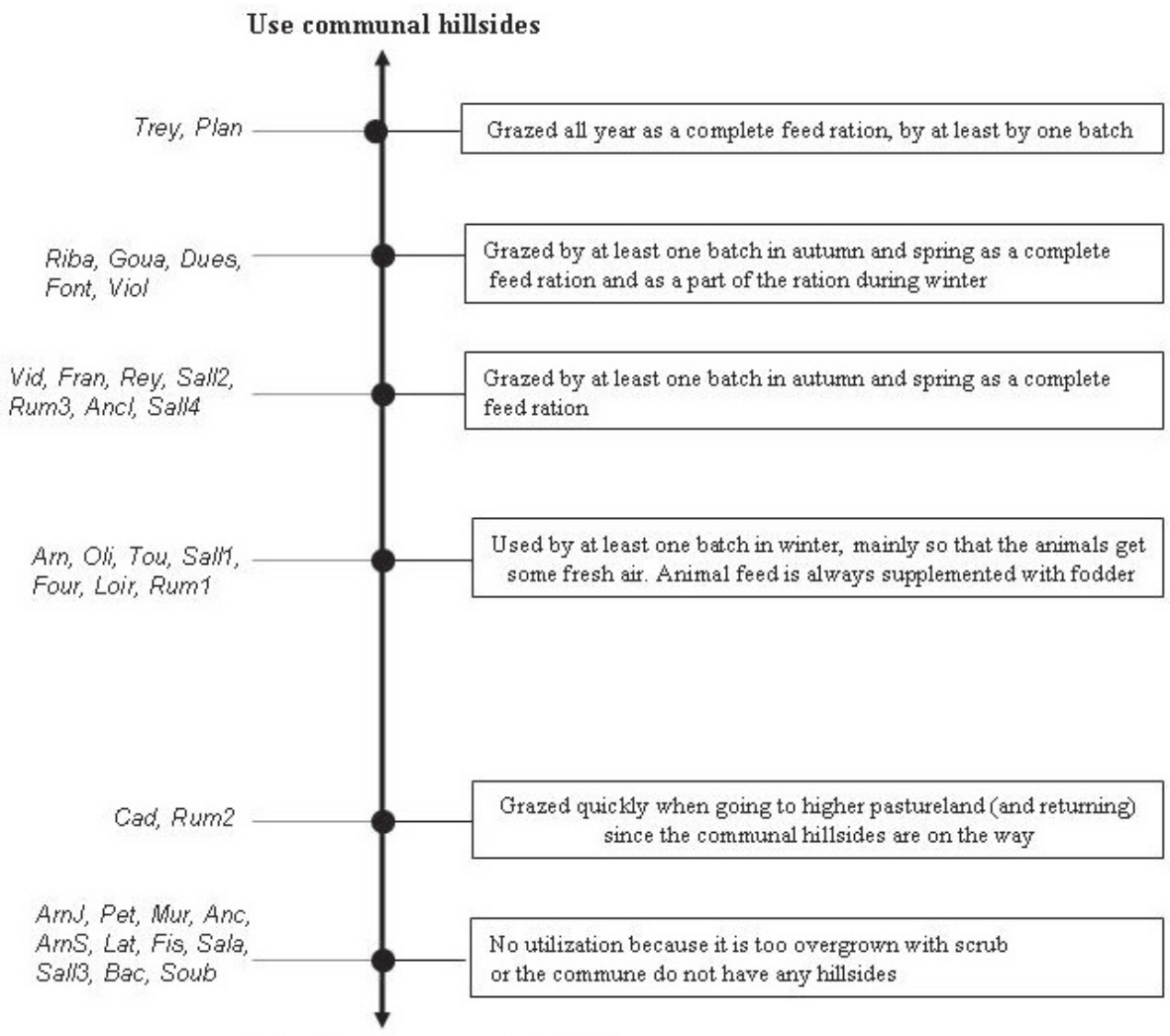

Do not use communal hillsides

identification codes of interviewed farmers
Practice modalities

Figure 2. The example of criterion 4 expressing the diversity of practices carried out by interviewed farmers concerning the use of communal hillsides. A criterion is represented by an axis opposing two extreme practices. Intermediate values are described in terms of practice modalities and farmers are classified by a point on the axis.

interview stage (B), and the clarification of each participant's expectations and role;

- Stage B consists of semi-structured interviews with farmers. Each interview is then summed up in an "interview summary", that is a standardised representation of collected data, as well as exact quotations of the way the farmer has described his practices in his own words. Such forms constitute the basis of the collective work of stage $\mathrm{C}$ with partners;

- Stage C consists of formalising the data acquired during stage $\mathrm{B}$ by bringing participants together in meetings and collectively identifying: (1) a set of diversity criteria; and (2) types that express different combinations of practices. A "diversity criterion" defines the practices carried out by interviewed farmers on an axis opposing two extreme practices (see Fig. 2 for an example). Intermediate values are thus characterised and farmers are classified by a point on this axis. To identify these criteria, the method proposes different tools such as the graphic translation of farming practices, interview summaries and the elicitation of expertise during working group meetings. On the basis of the prototypical theory (Rosch, 1978), types are defined by the most typical practices, using structural data only to enhance the picture. This last stage relies on a multivariate analysis provided by a repertory grid tool
(Gaines and Shaw, 1993); these tools are based on a multiple correspondence analysis and produce hierarchical classification trees that are used to cluster groups of cases that have the strongest similarities (see Fig. 3 for an example). This stage is highly iterative, combining a multivariate analysis with numerous group discussions that allow participants to express their own point of view on preliminary formalisations; hierarchical classification trees then serve as a representation tool to support discussions. The resulting typology thus highlights the hierarchies chosen by farmers in the way in which they really implement their strategy, as we will see in the Results section. Although this method is arduous because of the difficulty of acquiring and analysing data on practices, it has proven itself to be advantageous for participative approaches because it leads to a collective exploration of the problem (Girard, 2006).

\subsection{Farm sample}

The working group selected farms to be analysed on the basis of structural variables, which were identified as being potentially linked to land use, that is, livestock size, animal species or distribution chain. The final farm sample consisted of 33 farms out of the 113 farms in the district. The farm 


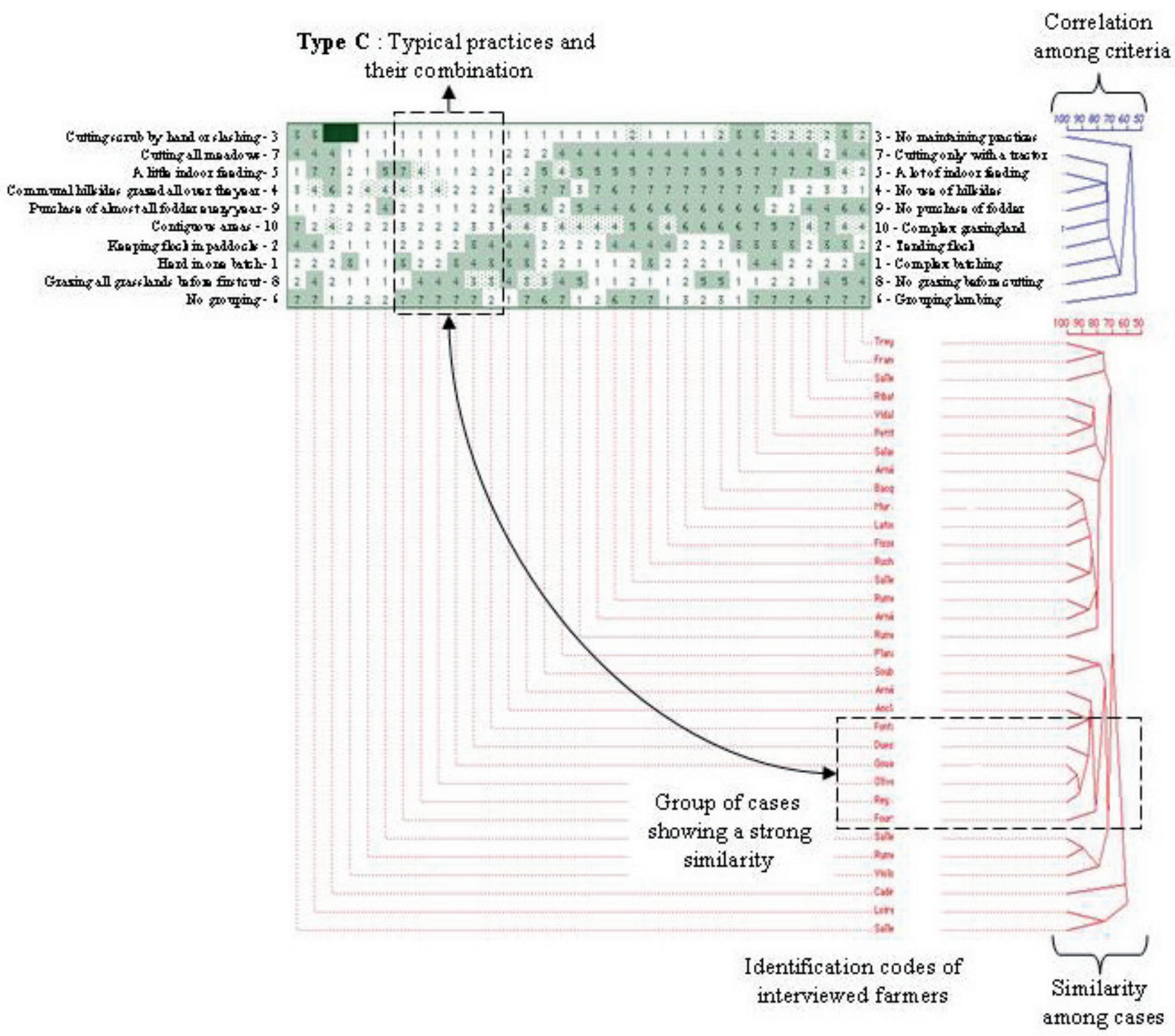

Figure 3. A repertory grid and the cluster analysis produced by WebgridIII showing correlations among criteria and similarities among practices carried out by farmers. Row headings are the two extreme practices for each of the ten criteria. Each number in this repertory grid corresponds to the practice modality carried out by the farmer (in columns) for a criterion (in rows). Analysing groups of farmers whose practices show strong similarities (such as the ones indicated on the figure) allowed us to define types of strategies.

sample was distributed over the 16 communes of the Arreau Valley in order to obtain results of interest to all of the participants. The 33 farmers were interviewed in spring and summer 2003.

All of the farmers interviewed were specialised in livestock. Most of these farms were devoted to monospecific livestock such as sheep, cattle, goats or horses, and only a quarter of them combined two or more species. The number of livestock units was highly diverse, ranging from almost 90 cattle to one or two cows. Farmland areas also varied considerably, from 3 to 65 ha. Only two farms had more than 50 ha. Twelve different livestock products were produced on the different farms, but two-thirds of the 33 farms only fed animals with grazed or supplied forages, producing store animals, whereas 11 farmers preferred to fatten some of their animals. All interviewed farmers used family labour. In almost half of the farms, there was a second family income, from the farmer himself or from his spouse.

\section{RESULTS AND DISCUSSION}

\subsection{Diversity of land-use practices by farmers in the Arreau Valley}

Ten criteria (Tab. I) were selected as being relevant to the problem of hillside use. These criteria concern: (i) livestock 
Table I. Ten criteria describing the diversity of livestock practices in the Arreau valley. Each criterion qualifies farmers' practices on an axis opposing two extreme practices.

\begin{tabular}{|c|c|c|}
\hline & Criterion & Extreme practices \\
\hline$\overline{1}$ & Splitting herds into batches & $\begin{array}{l}\text { - Driving herds to grazing land in one batch to simplify labour organisation } \\
\text { - Driving animals in batches and modifying batches during the year, to best } \\
\text { feed the animals in relation to their physiological state }\end{array}$ \\
\hline 2 & Leading animals to pasture & $\begin{array}{l}\text { - Tending flocks throughout the grazing season } \\
\text { - Keeping flocks in paddocks throughout the grazing season }\end{array}$ \\
\hline 3 & Maintaining grazed areas & $\begin{array}{l}\text { - Cutting scrub by hand or slashing and burning it to maintain grazed areas, } \\
\text { even in steep areas } \\
\text { - Maintaining grazed areas only with grazing to save labour }\end{array}$ \\
\hline$\overline{4}$ & Using the communal hillsides & $\begin{array}{l}\text { - Grazed all year round as a complete feed ration by at least one batch } \\
\text { - Not used }\end{array}$ \\
\hline 5 & $\begin{array}{l}\text { Indoor feeding or not according to grass } \\
\text { availability or to animals' needs }\end{array}$ & $\begin{array}{l}\text { - Fodder given as soon as animals return from summer pasture until late spring } \\
\text { for at least one batch of animals } \\
\text { - Fodder given beginning late in the autumn and ending as soon as animals are } \\
\text { turned out in spring in order to get the most out of pasture }\end{array}$ \\
\hline 7 & Technical choices to cut meadows & $\begin{array}{l}\text { - Cutting meadows only in tractor-accessible areas to save labour } \\
\text { - Cutting all meadows with a small mower driven by hand or by scythe }\end{array}$ \\
\hline$\overline{8}$ & Grazing or not before first cutting & $\begin{array}{l}\text { - No grazing before first cutting to allocate more land for haymaking } \\
\text { - Initially grazing nearly all the grassland fields before a possible cut to allow } \\
\text { early turnout }\end{array}$ \\
\hline 9 & Buying fodder or not & $\begin{array}{l}\text { - No purchase of fodder } \\
\text { - Purchase of almost all fodder every year }\end{array}$ \\
\hline$\overline{10}$ & Spatial configuration of grazed areas & $\begin{array}{l}\text { - Contiguous areas (hillsides and summer pasture) on the same side of the } \\
\text { valley, no lowland meadows } \\
\text { - Grazed areas in lowlands, hillsides and summer pastures, but not contiguous } \\
\text { and far from the farmstead }\end{array}$ \\
\hline
\end{tabular}

management, that is, splitting herds into batches, leading animals to pasture and breeding choices; (ii) the feeding system, which includes indoor feeding during the year, a hierarchy between haymaking and grazing in spring and the system's forage autonomy; and (iii) farmland utilisation and maintenance, which comprises hillside use, spatial configuration of grazed areas, maintenance practices and technical choices to cut meadows. For each criterion, extreme and intermediate practices were identified.

Moreover, each practice is characterised by an objective that explains the farmer's action. For example, in Figure 2, we describe the six different modalities for the practice, "using the communal hillsides" (criterion 4), and the reasons given by farmers to use them or not. Some farmers chose to use communal hillsides as an essential area in the grazing system; others chose a complex combination of hillsides with other areas, depending on the season. Some do not use hillsides at all.

Extreme values for a given criterion may therefore have a variety of explanations. For example, it could be animal performance for one value and labour supply for another (criterion 1). The main reasons given by farmers to account for their practices are related to land characteristics (criterion 10) and animal feeding and product quality (criteria 1, 5 and 6), whereas half of the criteria were related to labour simplification (criteria 1, 2, 3, 6 and 7). The feeding of animals and product quality also emerge as a top priority in these mountain areas, since it can be seen as the only way of being economically sustainable. Many practices aimed at reaching this target have been identified: splitting herds into batches (criterion 1), indoor feeding (criterion 5), giving priority to haymaking (criterion 8) and/or purchasing fodder (criterion 9) to provide for winter feeding.

\subsection{Diversity of land-use strategies of farmers}

Combining these ten criteria with the help of RepGrid allowed us to identify groups of farmers whose practices are similar (Fig. 3).

We analysed groups of farmers whose practices show strong similarities, and then defined six types of land-use strategies (Tab. II). These strategies reveal various combinations of practices and diverse hierarchies concerning the use of farmland areas. We also assigned descriptors to each of them in order to sum up the various rationales underlying 
Table II. Six types of strategies implemented by farmers in the Arreau Valley. Each type is described by the most typical practices carried out by interviewed farmers and their combination into a strategy. The six strategies are assigned a descriptor to sum up their rationales, thus revealing the various hierarchies concerning the use of farmland areas in the Arreau Valley.

\begin{tabular}{ll}
\hline Strategy & Typical practices and their combination \\
\hline A: Simplifying labour, while managing the farmland & - Clearing grazed fields with a scythe and/or slashing and burning in order to \\
& maintain good nutritive value as well as open landscapes \\
& - Feeding flocks with fodder until summer by precaution (rather than to control \\
& animal feeding) \\
& - Simplifying labour for flock management (no batches, paddocks), for breed- \\
& ing and selling (no fattening and opportunistic sales), and for haymaking (only \\
& on mechanised fields)
\end{tabular}

B: Feeding flocks mainly with grazing, while being con- $\quad$ - Feeding flocks mainly with grazing and providing fodder only during difficerned with farmland management cult months

- Using hillsides (communal as well as private ones) for spring and autumn grazing and for haymaking as well

- Clearing grazed fields with a scythe and/or slashing and burning to fight against shrub encroachment in order to maintain good nutritive value as well as open landscapes in these areas

- Simplifying labour for flock management (no batches), and for breeding and selling (no fattening and opportunistic sales)

C: Taking advantage of a farmland located on hillsides, while grouping births to sell store animals at Christmas
- Taking advantage of all of the farmland by grazing and limiting fodder given to animals

- Making hay wherever possible (even with a scythe) and keeping some grazed fields for first hay cutting

- Integrating hillsides into flock feeding, even for winter grazing

- Buying large quantities of fodder to complete harvested forage supplies

- Clearing grazed fields and communal areas by slashing and burning to fight against shrub encroachment, in order to maintain their forage potential

D: Foddering animals throughout the year and grouping births to sell store animals at Christmas, while limiting use of hillsides

- Giving fodder throughout the year to animals, regardless of their physiological states, to maintain their condition and to optimise production

- Reducing labour in pastures (not clearing fields with a scythe, cutting fields only with a tractor, regardless of forage supplies, not maintaining grazed fields by manual means) and devoting efforts to livestock (tending flocks throughout the grazing season by tradition and dedication in spite of the labour it requires)

- Keeping first grass growth in meadows in spring for grazing

- Grouping births and selling to specific distribution chains (store animals at Christmas)
E: Combining hillsides and lowlands, while grouping births to sell store animals at Christmas

- Combining the three farmland areas by designating their specific roles (lowland meadows for winter forage supplies, hillsides for spring and autumn grazing, high pastureland for summer grazing), in order to be self-sufficient for fodder and to sell products at a good price

- Feeding the flock mainly by grazing and providing fodder when necessary only to suckling animals

- Grouping births to sell store animals at Christmas

F: Giving great importance to feeding in order to fatten animals and to sell them on local marketing networks, while being concerned with farmland management
- Feeding fattened animals with care in order to sell a high quality product on local marketing networks

- Being very careful with suckling animal feeding (providing fodder over a long period to avoid any problems), in order to ensure lactation, and then fattening young animals

- Clearing grazed fields and communal areas by slashing and burning or with a scythe to fight against shrub encroachment, in order to maintain their forage potential, as well as maintaining open landscapes

- Simplifying routine flock labour (no batches, grazing in paddocks) 
their strategies: ensuring security (type A), maintaining heritage (type B), taking advantage of hillsides (type C), focusing on animal care (type D), combining areas, periods and batches (type E), and selling on local markets (type F).

Fodder autonomy (criterion 9) is very diverse. On the one hand, highly-dependent strategies (type C) entail the necessity of purchasing fodder for a farm located on the hillsides. On the other, autonomous strategies allow farmers to feed their flocks with home-grown forage. Nevertheless, such autonomy also depends on the farmer's choice of flock size. Even if typeA farmers all have entirely arable farmland, they are not all self-sufficient in terms of forage, which is determined by the flock/farmland size ratio.

Moreover, the role of grazing in flock feeding throughout the year reveals strategic choices between grazed feeding and supplementation, which means hay cutting or purchasing. Criteria 5 and 8 therefore oppose strategies that are based on supplemental feeding (types A and D), to various strategies that rely on grazing by supplementing late in autumn and turning out early in spring.

\subsection{The potential roles of farmers in the management of shrub-encroached hillsides in the Arreau Valley}

On the basis of our typology, we were able to link strategies chosen by farmers to the objectives of the local land-use management plan. We then identified the potential roles of farmers in the management of shrub-encroached hillsides, such as: (1) farmers' strategies that have the greatest impact on shrub encroachment; and (2) practices that may develop into more sustainable management of shrub encroachment.

For example, the use of hillsides (criterion 4: see Fig. 2) and the role of grazing in flock feeding (criteria 5 and 8) oppose two groups of different farmer types. Three types of farmers (types B, C and E) regularly use hillsides to feed their flocks, which is advantageous from the environmental point of view. Moreover, farmers using hillsides are able to keep lowland meadows for haymaking, thus reducing input costs. Types B, C and E thus offer innovative exemplary systems for those who do not use hillsides at all. Our results also highlight farmer types that should be helped by extension services within the land-use management plan. In particular, the type-C strategy that takes advantage of hillsides throughout the year is certainly the one with the greatest impact on shrub encroachment. These young type- $\mathrm{C}$ farmers are also the most fragile in terms of their labour load and fodder balance; since they do not have lowland meadows, they lack necessary forage supplies. Moreover, these steep hillsides are extremely labour-intensive. During the inquiry phase, these farmers expressed difficulties in achieving sustainability from both the economic and social points of view. They could greatly benefit from pastoral improvements adapted to hillsides such as watering points or fences, and from collective equipment such as roller choppers to restore open areas in the midst of shrubby vegetation.

Our results also shed light on ways to involve other farmers in the management of these hillsides. Changes in practices could be evaluated through the analysis of the type-E strategy, which relies on a combination of lowland meadows mainly devoted to stock production and hillsides grazed in spring. However, only three farmers in the interviewed sample used strategies similar to type E. Could farmers similar to type D move in this direction? One advantage would be to increase the available surface for grazing, making it possible to keep the first meadow growth for winter forage and thus to reduce forage purchases. On the other hand, such a change raises questions about: (i) the consequences on the organisation of labour (mainly for herd batching and moving animals from one place to another); and (ii) the doubts of type-D farmers regarding the forage value of hillside vegetation.

\subsection{Categorising farming practices to identify different development pathways and to design future research in agro-ecosystem management}

The categorisation approach we have taken leads to an understanding of the diversity of actual practices and strategies that can serve as a framework for facilitating learning among stakeholders. It is similar to the method used by Tefera et al. (2004), who take farm diversity representation as a prerequisite for designing more relevant extension actions. However, the types of strategies that we have built should not be confused with the "recommendation domain" concept, that is, a "group of farmers with similar practices and circumstances for whom a given recommendation would be broadly appropriate", developed by Williams (1994) to target research efforts. Actually, these recommendation domains consist of choosing the farmers who may adopt a given technology or who may be sensitive to a given technical message, within a dissemination perspective (Nagy and Sanders, 1990). They are thus based on a problem-solving approach in which extension relies on the predominant linear process; knowledge and technology are produced by research and then transferred to the end-users who are supposed to put it into action. Such a "top-down" process has been somewhat successful in the short term, but has also proved to be unsustainable and even "detrimental to both people and the ecosystem of which they are a part" for pastoral development (Russel and Ison, 2000). It is probably a dead end when encroachment management is at stake. The uncertainty inherent in ecological processes excludes any possibility of producing standardised and generic norms for encroachment management by grazing practices and, as a consequence, any top-down approach. In our research, we have shown that a comprehensive process revealing farmers' strategies could be a first step in overcoming the lack of technical references. By characterising a posteriori "accomplished strategies" from actual practices, our approach is also slightly different from work focusing on farmers' objectives and plans, e.g., studies of sociological "farming styles" (Fairweather and Keating, 1994), which highlight the way farmers see themselves what farming should be like, or those designing integrated crop management systems through theoretical prototypes (Lançon et al., 2007). 
In the Arreau Valley, our comprehensive approach of practices and strategies really carried out shed light on compromises chosen by farmers between:

- Feeding the different batches in order to obtain the right amount of feed at the right time;

- Managing encroachment by choosing the right grazing intensity at the right time.

The different compromises between these two goals that we have described result from different labour and economic situations, and also from patrimonial issues like those facing type-B farmers. These findings are in accordance with those of Miéville-Ott (2002), who showed that farmers' land use over the year results from a complex interaction between many factors and motivations. Understanding these reasons usually requires a specific, in-depth and disciplinary analysis. In our study, we show that it is possible to have a qualitative approach, focused on the combination of actual practices and on reasons expressed by farmers in their literal expression, without investigating these reasons more deeply.

The design of so-called "decision-aid tools" should therefore be seen from a learning perspective rather than a normative one. The role of such learning tools is to enrich the picture that stakeholders have of the situation; this is particularly true when exploring and evaluating different land-use scenarios at the farm level (Jakeman and Letcher, 2003).

Identifying grazing practices that have an impact on shrub dynamics cannot be separated from the analysis of farmers' strategies. Thus, understanding these strategies is a key stage for research; it is necessary to guide modelling efforts on shrub population dynamics in unconventional but relevant ways. The typology of strategies in the Arreau Valley revealed the diversity of functions that farmers attribute to the hillsides in their feeding system: from a real feeding function (type E) to one that consists of letting the animals out to get air and exercise (type F). Combining production and environmental goals will be an issue for type-B farmers but not for type-F. Moreover, farmers' land-use strategies create a framework within which a particular plot could be grazed. At the paddock level, innovative agroecological models now combine animal feeding behaviour processes with shrub population dynamics processes to identify grazing practices with major impacts on encroachment (Magda et al., 2001). Such models generally end up with the identification of an efficient grazing mode. However, they do not deal with the question of implementing such grazing modes within the context of a particular farm. Taking strategy diversity into account will thus help to:

- categorise grazing modes and their objectives according to their impact on shrub dynamics;

- predict encroachment risks for each type of management practice and each degree of encroachment;

- propose adjustments of practices on a long-term basis, which are compatible and coherent with the actual strategy.

Categorising farming practices also meets a current and important need for agronomical research, which is to encompass and combine different levels of analysis: the plot and farmland level, as described above, as well as the valley level, taking the spatial localisation of the farms in the territory (bottom of the valley, hillsides) and their potential complementary nature into account. When crossing scales and domains (environmental, economic, social or cultural), threshold interactions can be identified to promote actions at the appropriate level and to evaluate their consequences (Kinzig et al., 2006). Most often, technical actions are designed at the plot level and added together to propose innovative systems; they thus determine, mainly through simulation models, management practices at subsequent levels. However, such an approach bypasses the fact that determinants of agricultural practices operate at higher levels, usually taking a set of criteria and the coordination in space and time of the different technical actions into account (McCown et al., 2001; Biarnès et al., 2004). Lançon et al. (2007) argue for an integrated approach to design and assess sustainable crop management systems adapted to specific local constraints. They developed an innovative methodology combining expert knowledge, cropping constraints and farmers' objectives. Similarly, our typology of strategies clearly shows that encroachment management must be considered on different scales - the plot and farm - but also at the level of the valley.

Simulations of spatial and temporal actions such as cutting and grazing on the farm scale need to create data on the available feed resources that these land areas can provide and on the grazing intensity and frequency needed to maintain acceptable vegetation states. Building land-use scenarios at the farm level could thus be based on:

- sound data for land areas without any risk of encroachment, mainly fields located in the bottom of the valley and on hillsides for those that are cut, in order to use generic models for herbage growth and quality (Jouven et al., 2006);

- fuzzy data concerning the management practices that make it possible to reach different vegetation states on hillsides for those that are grazed only;

- a generic modelling framework combining management practices in space and time, leading to consistent feeding systems according to available land (Cros et al., 2004).

Methodological advances can probably be made by combining: (i) a method, e.g., a fuzzy model, for taking uncertainty regarding the effect of management practices on hillside vegetation into account (Cornelissen et al., 2001), and (ii) a conceptual model for simulating farmers' decisions (Su et al., 2005).

\section{CONCLUSION}

Based on a comprehensive approach and a partnership with local land-use managers in a valley in the French Pyrenees, this work aimed at exploring the potential contribution of livestock farms to shrub encroachment control. Our results show that the diversity of land-use practices by livestock farmers can be summed up by ten practices related to livestock management, the feeding system and farmland utilisation and maintenance. We also show that farmers combine these practices within six types of actual strategies. With this typology, we identified strategies used by farmers that have the greatest impact on shrub encroachment: types B, E and especially C, which attempts to take advantage of hillsides throughout the 
year. This type-C strategy mainly concerns young farmers who deserve to benefit from pastoral improvements. Our results also highlight innovative practices that lead to more sustainable management of shrub encroachment. For example, in spring, the type-E strategy combines grazing hillsides and cutting lowland meadows for stock production; such practices offer the advantage of increasing the surface available for grazing, making it possible to keep the first meadow growth for winter forage and thus to reduce forage purchases. This suggests that some farmers, e.g., type-D, who focus on animal care, could be encouraged to move in this direction. However, consequences on the organisation of labour and how farmers perceive the forage value of hillside vegetation should be studied in more depth and, above all, discussed with the stakeholders concerned. Our categorisation work highlights the fact that the contribution of such representations is not so much to quantify the effect of a set of decision rules on shrub encroachment or herd performances, but rather to encourage the emergence of new solutions resulting from the supply of new information. In this way, farmers and land managers can integrate these solutions into their own ideas, which may go beyond the necessarily restricted scope of our work. Such an approach may be seen as a first step in imagining new relationships between research and development and, from a broader point of view, between science and society.

Acknowledgements: The authors would like to thank Florence Dufourcq for her help with data collection and analysis, the farmers who took part in the interview, and Gail Wagman for improving the English. This work was funded by INRA and the Midi-Pyrenees region within the framework of the PSDR programme.

\section{REFERENCES}

Andersen E., Elbersen B., Godeschalk F. (2004) Sustaining agriculture and the rural environment, Govern., Pol. Multifunct., 104-123.

Andrieu N., Josien E., Duru M. (2007) Relationships between diversity of grassland vegetation, field characteristics on land use management practices assessed at the farm level, Agr. Ecosyst. Environ. 120, 359-369.

Balent G., Gibon A. (1999) Organisation collective et individuelle dans la gestion des ressources pastorales : conséquences sur la durabilité agro-écologique des ressources, in: Gibon A., Lasseur J., Manrique E., Masson P., Pluvinage J., Revilla R. (Eds.), Livestock farming systems and land management in the mountain and hill Mediterranean regions, CIHEAM-IAMZ, Zaragoza, pp. 267-277.

Beyene A., Gibbon D., Haile M. (2006) Heterogeneity in land resources and diversity in farming practices in Tigray, Ethiopian Agr. Syst. $88,61-74$.

Biarnès A., Rio P., Hocheux A. (2004) Analyzing the determinants of spatial distribution of weed control practices in a Langudoc vineyard catchment, Agronomie 24, 187-196.

Bradshaw J.M., Ford K.M., Adams-Webber J.R., Boose J.H. (1993) Beyond the repertory grid: new approaches to constructivist knowledge acquisition tool development, Int. J. Intell. Syst. 8, 287-333.

Bravo L. (1980) We are losing the war against broom, Fremontia 15, $27-$ 29.

Buller H., Wilson G.H., Höll A. (2000) European agri-environmental policy in the European Union, Ashgate Publishing Ltd. Basingstoke, UK.
Checkland P. (1981) Systems Thinking, Systems Practice, John Wiley and Sons, New York.

Cornelissen A.M.G., van den Berg J., Koops W.J., Grossman M., Udo H.M.J. (2001) Assessment of the contribution of sustainability indicators to sustainable development: a novel approach using fuzzy set theory, Agr. Ecosyst. Environ. 86, 173-185.

Cros M.J., Duru M., Garcia F., Martin-Clouaire R. (2004) Simulating management strategies: the rotational grazing example, Agr. Syst. $80,23-42$.

Douthwaite B., Delve R., Ekboir J., Twomlow S. (2003) Contending with complexity: the role of evaluation in implementing sustainable natural resource management, Int. J. Agric. Sustain. 1, 51-66.

Fairweather J.R., Keating N.C. (1994) Goals and management styles of New Zealand Farmers, Agr. Syst. 44, 181-200.

Fry G., Tress B., Tress G. (2004) The potential and limitations of integrated grassland research, Grassl. Sci. Eur. 9, 1157-1167.

Gaines B.R., Shaw M.L.G. (1993) Knowledge acquisition tools based on personal construct psychology, Knowl. Eng. Rev. 8, 49-85.

Girard N. (2006) Catégoriser les pratiques d'agriculteurs pour reformuler un problème en partenariat. Une proposition méthodologique, Cahiers Agric. 15, 261-272.

Girard N., Bellon S., Hubert B., Lardon S., Moulin C.H., Osty P.L. (2001) Categorising combinations of farmers' land use practices: an approach based on examples of sheep farms in the south of France, Agronomie 21, 435-459.

Ison R.L. (1993) Soft systems: a non-computer view of decision support, in: Stuth J.W., Lyons B.G. (Eds.), Decision support systems for the management of grazing lands. Emerging issues, UNESCO \& Parthenon Publishing Group, pp. 83-121.

Jakeman A.J., Letcher R.A. (2003) Integrated assessment and modelling: features, principles and examples for catchment management, Environ. Modell. Softw. 18, 491-501.

Jouven M., Carrere P., Baumont R. (2006) Model predicting dynamics of biomass, structure and digestibility of herbage in managed permanent pastures. 1. Model description, Grass Forage Sci. 61, 112-124.

Kinzig A.P., Ryan P., Etienne M., Allison H., Elmqvist T., Walter B.H. (2006) Resilience and regime shifts: assessing cascading effects, Ecol. Soc. 11 (ecologyandsociety.org/vol11/iss/art20).

Köbrich C., Rehman T., Khan M. (2003) Typification of farming systems for constructing representative farm models: two illustrations of the application of multivariate analysis in Chile and Pakistan, Agr. Syst. 76, 141-157.

Lançon J., Wery J., Rapiedl B., Angokaye M., Gérardeaux E., Gaborel Ch., Ballo D., Fadegnon B. (2007) An improved methodology for integrated crop management systems, Agron. Sustain. Dev. 27, $101-110$

Landais E. (1998) Modelling farm diversity. New approaches to typology building in France, Agr. Syst. 58, 505-527.

Mac Cown R.L. (2001) Learning to bridge the gap between sciencebased decision support and the practice of farming: Evolution in paradigms of model-based research and intervention from design to dialogue, Aust. J. Agr. Res. 52, 549-571.

Magda D., Meuret M., Hazard L., Agreil C. (2001) Répondre à une politique de conservation de la biodiversité : le pâturage des brebis pour la maîtrise des landes à genêts, FaçSADe 12,1-4.

Mattison E.H.A., Norris K. (2005) Bridging the gaps between agricultural policy, land-use and biodiversity, Trends Ecol. Evol. 20, 610-616.

Miéville-Ott V. (2002) Multifunctionality and farmers' identity, in: Proceedings of the 19th General Meeting on "Multi-Function Grasslands: Quality Forages, Animal Products and Landscapes", European Grasslands Federation, INRA/AFPF, Versailles. 
Mintzberg H., Waters J.A. (1985) Of strategies deliberate and emergent, Strat. Manag. J. 6, 257-272.

Mottet A., Ladet S., Coque N., Gibon A. (2006) Agricultural land-use change and its drivers in mountain landscapes: A case study in the Pyrenees, Agr. Ecosyst. Environ. 114, 296-310.

Nagy J.G., Sanders J.H. (1990) Agricultural technology development and dissemination within a Farming Systems perspective, Agr. Syst. 32, 305-320.

Nesme T., Bellon S., Lescourret F., Habib R. (2006) Survey-based analysis of irrigation and $\mathrm{N}$ fertilisation practices in apple orchards, Agron. Sustain. Dev. 26, 215-225.

Pearson C.J., Zuo H., Valentine I., Unkovich M. (2003) Sustainability of Grazing Systems: Feed Base, Critical Grazing Pressure and Variability, Int. J. Agr. Sustain. 1, 95-107.

Plieninger T. (2006) Habitat loss, fragmentation, and alterationQuantifying the impact of land-use changes on a Spanish dehesa landscape by use of aerial photography and GIS, Landscape Ecol. 21, 91-105.

Röling N. (2003) From causes to reasons: the human dimension of agricultural sustainability, Int. J. Agr. Sustain. 1, 73-88.

Röling N., Jiggins J. (1998) The ecological system, in: Röling N., Wagemakers M.A.E. (Eds.), Facilitating sustainable agriculture: participatory learning and adaptive management in times of environmental uncertainty, Cambridge University Press, Cambridge UK, pp. 281-307.

Rosch E. (1978) Principle of categorization, in: Rosch E., Lloyd B.B. (Eds.), Cognition and categorization. Lawrence Erlbaum Associates, pp. 27-48.

Russell D.B., Ison R.L. (2000) The research development relationship in rural communities: an opportunity for contextual science, in: Ison
R.L., Russel D.B. (Eds.), Agricultural extension and rural development: breaking out traditions. Cambridge University Press, Cambridge (UK), pp. 10-31.

Simon H.A. (1978) Rationality as process and as a product of thought, Am. Econ. Rev. 68, 1-16.

Su X.F., Asseng S., Campbell P., Cook F., Schilizzi S., Nancarrow B., Poole M., Carlin G., Brockman H. (2005) A conceptual model for simulating farmer decisions and land use change, in: Proceedings of the MODSIM 05 International Congress on Modelling and Simulation. Advances and Applications for Management and Decision Making, Melbourne, Australia, pp. 156-161.

Swift M.J., Izac A.-M.N., Noordwijk van M. (2004) Biodiversity and ecosystem services in agricultural landscapes - are we asking the right questions? Agr. Ecosyst. Environ. 104, 113-134.

Tefera T.L., Perret S., Kirsten J.F. (2004) Diversity in livelihoods and farmers' strategies in the Hararghe Highlands, Eastern Ethiopia, Int. J. Agr. Sustain. 2, 133-146.

Van Keulen H. (2006) Heterogeneity and diversity in less-favoured areas, Agr. Syst. 88, 1-7.

Wallis De Vries M.F., Bakker J.P., Van Wieren S.E. (1998) Grazing and Conservation Management, Kluwer Academic Publishers, Dordrecht, the Netherlands.

Walker D.H. (2002) Decision support, learning and rural resource management, Agr. Syst. 73, 113-127.

Williams T.O. (1994) Identifying target groups for livestock improvement research: the classification of sedentary livestock producers in Western Niger, Agr. Syst. 46, 227-237.

White T.A., Barker D.J., Moore K.J. (2004) Vegetation diversity, growth, quality and decomposition in managed grasslands, Agr. Ecosyst. Environ. 101, 73-84. 